\title{
Reinforcement benefits of nanomodified coir fiber in lime-treated marine clay
}

\begin{abstract}
In this study, reinforcing effect of nanomodified coir fibers with ferric hydroxide, $\mathrm{Fe}(\mathrm{OH}) 3$, and aluminum hydroxide, $\mathrm{Al}(\mathrm{OH}) 3$, on shear strength of limed marine clay soil was investigated. Accordingly, triaxial compression strength (TCS) testing was carried out to determine the shear strength parameters of the reinforced soil. Also, wetting/drying cycle testing was conducted to assess the durability of samples. The results from the experimental investigation show that the lime and nanomodified fibers improved the shear strength and durability through the intended modification on natural coir fiber. Moreover, an increase in the effective stress internal friction angle and the cohesion intercept were observed. To confirm the morphology alteration in fibers, scanning electron microscopy (SEM) and energy dispersive X-ray (EDX) tests were performed. Nanomodification of fibers increased their tensile strength and caused a better interaction with the limed matrix by an enhanced interfacial adhesion. The tensile strength and friction at the interface was the dominant mechanism controlling the reinforcement benefit.
\end{abstract}

Keyword: Nanomodified; Coir fiber; Lime-treated marine clay 